\title{
ANALISIS STRATEGI PENGEMBANGAN DAN UJI KELAYAKAN USAHA KECIL MENENGAH AMPLANG IKAN DI KOTA TARAKAN
}

\author{
ANALYSIS OF DEVELOPMENT STRATEGY AND FEASIBILITY TEAM OF \\ FISHING SMALL AND MEDIUM ENTERPRISES AMPLANG IN THE CITY OF \\ TARAKAN
}

\author{
Syaiful Anwar ${ }^{1)}$, Narmiana ${ }^{2)}$ \\ ${ }^{1) 2)}$ Universitas Borneo Tarakan \\ Gmail: ${ }^{2}$ Narmianainar95@gmail.com
}

\begin{abstract}
Abstrak : Penelitian ini bertujuan untuk mengetahui strategi dan analisis yang digunakan dalam pengembangan usaha amplang ikan di Kota Tarakan. Jenis penelitian ini yaitu penelitian deskriptif dengan menggunakan pendekatan kualitatif dan kuantitatif. Populasi dalam penelitian ini adalah seluruh pengusaha amplang yang ada di kota Tarakan baik terdaftar di dinas yang terkait maupun tidak. Adapun populasi penelitian ini berjmlah 14 orang dengan pengambilan sampel menggunakan teknik sampel jenuh atau teknik sampel sensus dimana semua populasi dijadikan sampel, dan data penelitian ini menggunakan data primer dan data sekunder. Berdasarkan hasil penelitian ini diketahui bahwa kelayakan finansial dilihat dari BCR (Benefit Cost of Ratio) sebesar 1.03, NPV (Net Present Value) sebesar 172.927.700,60, FRR (Financial Rate of Return) sebesar 98,51\%, PBP (Pay Back Period) sebesar 1,02 dan BEP (Break Even Point) dasar harga unit sebanyk 15,000 bungkus dan dasar harga penjualan sebesar Rp18.000.000. Berdasarkan kriteria kelayakan yang telah ditentukan dapat dikatakan bahwa UKM amplang ikan di Kota Tarakan layak untuk di operasionalkan. Sedangkan tahapan analisis yang dilakukan yaitu dengan melihat kondisi internal dan eksternal perusahaan dengan cara analisis situasi dengan kata lain yaitu analisis SWOT, dengan melalui tahapan IFE (Internal Faktor Evaluation), EFE (Eksternal Faktor Evaluation), diagram SWOT dan Matriks SWOT. Hasil analisis data menunjukkan bahwa strategi yang digunakan yaitu strategi Agresif atau strategi SO (strength-Opportunity).
\end{abstract}

\section{Kata Kunci: Strategi Pengembangan, Kelayakan Usaha Finansial}

Abstract : Research this aim for knowing strategy and the analysis in business development amplang fish in town Tarakan. Type research this that is research descriptive with use approach qualitative and quantitative. Population in research this is whole businessman amplang in town Tarakan good registered in the service related as well no. As for population research this amounted to 14 people with taking sample use technique a sample saturated or technique sample census where all population made sample, and research data this using primary data and secondary data. Based on results research this is known that appropriateness financial seen from BCR (Benefit Cost of Ratio) of 1.03, NPV (Net Present Value) of 172.927.700,60, FRR (Financial Rate of Return) of 98,51\%, PBP (Pay Back Period) of 1.02 and BEP (Break Even Point) basis amount unit price of 15,000 
packs and basis price sales of Rp18,000,000. Based on criteria eligibility that has been determined could it says that the are envelopes fish in town Tarakan feasible for operating. While stages analysis conducted that is with look internal conditions and external company with way analysis situation in other words is SWOT analysis, with through IFE (Evaluation of Internal Factors) stages, EFE (Evaluation of External Factors), SWOT diagrams and SWOT Matrix. Results data analysis shows that strategies used that is strategy Aggressive or SO strategy (strength-Opportunity).

Keywords: Strategy Development, Financial Feasibility

\section{LATAR BELAKANG}

Pengembangan usaha kecil menengah (UKM) menjadi suatu hal yang demikian penting untuk pertumbuhan ekonomi sebuah negara termasuk di negara Indonesia. Disamping itu, UKM mempunyai kontribusi terhadap penyerapan tenaga kerja (Tambunan dalam Purnendu, 2005). Peran UKM sangat penting bagi perekonomian diantaranya sebagai penyedia barang dan jasa, penyerapan tenaga kerja serta merupakan salah satu penggerak perekonomian negara. Masalah pertumbuhan ekonomi di Indonesia sangat erat kaitannya dengan pengangguran yang jumlahnya semakin banyak. Masalah pengangguran bukanlah hal yang bisa disepelekan, pengangguran seringkali menjadi masalah dalam perekonomian. Karena adanya pengangguran, produktivitas dan pendapatan masyarakat akan berkurang sehingga dapat menyebabkan timbulnya kemiskinan. Apabila kondisi perekonomian baik maka secara otomatis penyerapan tenaga kerja juga baik.

Oleh karena itu, kehadiran UKM harus di dukung penuh terutama oleh pemerintah.
Pengembangan usaha erat kaitannya dengan wirausaha dimana wirausaha merupakan salah satu solusi untuk membantu mengurangi jumlah pengangguran dengan cara membuka lapangan kerja baru dengan tujuan mengurangi tingkat pengangguran di Indonesia. Permasalahan yang dihadapi UKM diantaranya kurangnya permodalan, kesulitan dalam pemasaran, struktur organisasi sederhana dengan pembagian kerja yang tidak baku, sumber daya manusia terbatas dan kualitasnya rendah, serta rendahnya kualitas teknologi menurut (Situmorang dalam Arief Rahmana, 2010). Permasalahan ini mengakibatkan lemahnya jaringan usaha, skala ekonomi terlalu kecil dan terlebih lagi UKM yang tidak memiliki keunggulan kompetitif. Oleh karena itu, perlu adanya strategi pengembangan UKM untuk mendukung kegiatan ekonomi guna memiliki nilai tambah dan berdaya saing tinggi, tidak hanya memiliki keunggulan komparatif melainkan keunggulan kompetitif.

Selain strategi pengembangan yang dilakukan dalam suatu usaha, maka dilakukan pula analisis kelayakan untuk mengetahui tingkat kelayakan UKM tersebut. Studi 
kelayakan bisnis/usaha adalah suatu penelitian tentang layak atau tidaknya suatu investasi bisnis dilaksanakan. Studi kelayakan bisnis merupakan penelitian terhadap rencana bisnis yang tidak hanya menganalisis layak atau tidak layak bisnis dibangun, tetapi juga saat dioperasikan secara rutin dalam rangka pencapaian keuntungan yang maksimal untuk waktu yang tidak ditentukan (Umar, 2005:8). Sedangkan menurut (Kasmir dalam Abdi Tri Sulistyo, 2014) studi kelayakan bisnis/usaha adalah kegiatan yang mempelajari secara mendalam tentang suatu kegiatan usaha atau bisnis yang dijalankan, dalam rangka menentukan layak atau tidak usaha tersebut dijalankan. Dengan kata lain kelayakan dapat diartikan bahwa usaha yang dijalankan akan memberi keuntungan finansial sesuai dengan tujuan yang mereka inginkan. Jadi layak atau tidaknya UKM dapat ditentukan dari analisis kelayakan agar suatu usaha dapat memiliki prospek yang baik dalam jangka panjang.

Potensi UKM di Propinsi Kalimantan Utara khususnya di Kota Tarakan cukup besar yang didukung oleh sumber daya alam yang dimiliki oleh Kota Tarakan yang berlimpah telah memberikan kontribusi yang signifikan terhadap perekonomian masyarakat Kota Tarakan. Potensi yang dapat dikembangkan diantaranya sektor kelautan dan perikanan, sektor pariwisata, sektor industri dan sektor perdagangan. Dengan berbagai potensi tersebut, Peluang pengembangan UKM menjadi strategis, diketahui bahwa wilayah Kalimantan Utara yang berbatasan langsung dengan
Malaysia menjadikan UKM harus berbenah diri dalam meningkatkan daya saingnya. Namun kondisi di Kota Tarakan masih lemah dalam berbagai aspek usaha, diantaranya aspek kemampuan sumber daya manusia, sarana dan prasarana, permodalan serta pemasaran. Untuk itu strategi pengembangan perlu dirumuskan dalam membuat kebijakan pemberdayaan UKM di Kota Tarakan. Upaya yang dilakukan pemerintah dengan memberikan motivasi terhadap pelaku UKM agar mereka lebih bersemangat dalam mengembangkan usahanya, termasuk dengan memberikan pelatihan dan bimbingan agar produktifitas pelaku UKM dapat meningkat sehingga akan tumbuh dengan daya dukung yang memadai sehingga meningkatkan taraf kualitas bagi masyarakat. Salah satu hal yang menarik untuk diteliti mengenai pengembangan dan kelayakan usaha adalah usaha amplang ikan yang ada di Kota Tarakan. Amplang ikan merupakan sejenis kerupuk dengan cita rasa dan aroma ikan yang khas. Terlebih lagi amplang ikan merupakan salah satu ciri khas Kalimantan dan menjadi oleh- oleh dari Kalimantan khususnya di Kota Tarakan. Jadi penulis merasa perlu dilakukan penelitian terhadap potensi terpendam di dalam kegiatan usaha amplang ikan di Kota Tarakan yang dapat dikembangkan menjadi kekuatan bisnis serta menganalisis kelayakan apakah usaha amplang ikan tersebut layak diteruskan atau tidak.Mengingat pentingnya masalah tersebut maka penulis tertarik melakukan penelitian ilmiah yang berjudul "Analisis Strategi Pengembangan dan Uji Kelayakan 
Usaha Kecil Menengah Amplang Ikan di Kota Tarakan".

\section{RUMUSAN MASALAH}

Berdasarkan latar belakang di atas, maka yang menjadi pertanyaan penelitian ini adalah:

1. Bagaimana strategi pengembangan usahaamplang ikan di Kota Tarakan

2. Bagaimana tingkat kelayakan usaha amplang ikan di Kota Tarakan

\section{TUJUAN PENELITIAN}

1. Menjelaskan pengembanganusaha ikan di Kota Tarakan

strategi amplang

2. Menganalisis tingkat kelayakan usaha amplang ikan di Kota Tarakan

\section{TINJAUAN PUSTAKA}

\section{Tinjauan Teoritis}

Daerah $\begin{gathered}\text { Pembangunan } \\ \text { Menurut }\end{gathered} \begin{array}{r}\text { Ekonomi } \\ \text { (Arsyaddalam }\end{array}$ Kasan Lathoif, 2011) Pembangunan ekonomi daerah adalah suatu proses dimana pemerintah daerah dan masyarakatnya mengelola sumber daya-sumber daya yang ada dan membentuk suatu pola kemitraan antara pemerintah daerah dengan sektor swasta untuk menciptakan suatu lapangan kerja baru dan merangsang perkembangan kegiatan ekonomi atau pertumbuhan ekonomidalam wilayah tersebut.

$$
\text { Pembangunan ekonomi }
$$

daerah mencakup pembentukan institusi- institusi baru, pembangunan industri-industri alternatif, perbaikan kapasitas tenaga kerja yang ada untuk menghasilkan produk dan jasa yang lebih baik, dan identifikasi pasar-pasar baru. Secara umum tujuan pembangunan ekonomi daerah adalah untuk mengembangkan lapangan kerja bagi penduduk. Dalam pelaksanaan pembangunan ekonomi daerah, perlu adanya strategi pengembangan ekonomi daerah yang baik dan terarah agar mencapai tujuan dan sasaran yang diinginkan. Tenaga Kerja Menurut (Sidijatmo Kusumawidho,1998:53) tenaga kerja adalah seluruh penduduk suatu negara yang dapat memproduksi barang dan jasa, jika ada permintaan terhadap tenaga kerja dan jika mereka mau berpartisipasi dalam aktivitas tersebut.

Menurut Undang Undang Nomor 13 tahun 2003 Bab I pasal 1 ayat 2 disebutkan bahwa tenaga kerja adalah setiap orang yang mampu melakukan pekerjaan guna menghasilkan barang dan atau jasa baik untuk memenuhi kebutuhan sendiri maupun untuk masyarakat. Ada bebrapa Klasifikasi tenaga kerja, diantaranya :

Berdasarkan Penduduknya:

1. Tenaga kerja adalah jumlah penduduk yang dianggap dapat bekerja dan sanggup bekerja jika ada permintaan kerja.

2. Bukan tenaga kerja adalah mereka yang dianggap tidak mampu dan tidak mau bekerja meskipun ada permintaan kerja. Contohnya para pensiun, lansia dan anak-anak.

Berdasarkan batas kerja :

1. Angkatan kerja adalah penduduk usia produktif yang berusia 15-64 
tahun yang sudah mempunyai pekerjaan tetapi sementara tidak bekerja, maupun yang sedang aktif mencari pekerjaan.

2. Bukan angkatan kerja adalah mereka yang berumur 10 tahun keatas yang kegiatannya hanya bersekolah, mengurus rumah tangga dan sebagainya. Contohnya anak sekolah, mahasiswa, ibu rumah tangga dan orang cacat.

\section{Penyerapan tenaga kerja}

Penyerapan tenaga kerja merupakan jumlah tertentu dari tenaga kerja yang digunakan dalam suatu unit usaha tertentu atau dengan kata lain penyerapan tenaga kerja adalah jumlah tenaga kerja yang bekerja dalam suatu unit usaha. Menurut (Sonny Sumarsono, 2003:105) Permintaan tenaga kerja berkaitan dengan jumlah tenaga kerja yang dibutuhkan oleh perusahaan atau instansi, dimana faktor yang mempengaruhi penyerapan akan tenaga kerja adalah:

1. Tingkat Upah Perubahan tingkat upah akan mempengaruhi tinggi rendahnya biaya produksi perusahaan. Apabila digunakan asumsi bahwa tingkat upah naik, maka akan terjadi hal-hal sebagai berikut:

a. Naiknya tingkat upah akan meningkatkan biaya produksi perusahaan, yang selanjutnya akan meningkatkan pula harga per unit barang yang diproduksi. Biasanya para konsumen akan memberikan respon yang cepat apabila terjadi kenaikan harga barang, yaitu mengurangi konsumsi atau bahkan tidak lagi mau membeli barang yang bersangkutan. Akibatnya banyak barang yang tidak terjual, dan terpaksa produsen menurunkan jumlah produksinya. Turunnya target produksi, mengakibatkan berkurangnya tenaga kerja yang dibutuhkan (Sonny Sumarsono, 2003:105).

b. Menurut (Sonny Sumarsono, 2003:106), yang menyatakan bahwa: Permintaan tenaga kerja dipengaruhi oleh perubahan tingkat upah. Apabila upah naik (asumsi harga dari barang-barang modal lainnya tidak berubah), maka pengusaha ada yang lebih suka menggunakan teknologi padat modal untuk proses produksinya dan menggantikan kebutuhan akan tenaga kerja dengan kebutuhan akan barangbarang modal seperti mesin dan lainnya. Penurunan jumlah tenaga kerja yang dibutuhkan karena adanya penggantian atau penambahan penggunaan mesin-mesin disebut dengan efek substitusi tenaga kerja (substitution effect).

2. Nilai Produksi Menurut (Sonny Sumarsono, 2003:106), menyatakan nilai produksi adalah tingkat produksi atau keseluruhan jumlah barang yang merupakan hasil akhir proses produksi pada suatu unit usaha yang selanjutnya akan dijual atau sampai ke tangan konsumen. Naik turunnya permintaan pasar akan hasil 
produksi dari perusahaan yang bersangkutan. Apabila permintaan hasil produksi perusahaan atau industri meningkat, produsen cenderung untuk menambah kapasitas produksinya. Untuk maksud tersebut produsen akan menambah penggunaan tenaga kerjanya. Perubahan yang mempengaruhi permintaan hasil produksi, antara lain naik turunnya permintaan pasar akan hasil produksi dari perusahaan yang bersangkutan, tercermin melalui besarnya volume produksi, dan harga barangbarang modal yaitu nilai mesin atau alat yang digunakan dalam proses produksi.

\section{$\underline{\text { Strategi Pengembangan }}$}

1. Definisi Perencanaan Strategis Suatu perusahaan dapat mengembangkan strategis untuk mengatasi ancaman eksternal dan merebut peluang yang ada. Proses analisis, perumusan dan evaluasi strategi-strategi itu disebut perencanaan strategi. Tujuan utama perencanaan strategis adalah agar perusahaan dapat melihat secara objektif kondisi-kondisi internal dan eksternal, sehingga perusahan dapat mengantisipasi perubahan perubahan lingkunga eksternal.

2. Konsep Strategi Definisi strategi pertama yang dikemukakan oleh Chandler (1965:13) menyebutkan bahwa "strategi adalah tujuan jangka panjang dari suatu perusahaan, serta pendayagunaan dan alokasi semua sumber daya yang penting untuk mencapai tujuan tersebut".Pemahaman yang baik mengenai konsep strategi dan konsep-konsep lain yang berkaitan, sangat menentukan suksesnya strategi yang disusun. Studi Kelayakan Menurut (Ibrahim, 2003:1) yang menyatakan bahwa "studi kelayakan bisnis merupakan bahan pertimbangan dalam mengambil suatu keputusan, apakah menerima atau menolak dari suatu gagasan usaha atau proyek yang direncanakan". Maksud layak atau tidak layak di sini adalah prakiraan bahwa proyek akan dapat atau tidak dapat menghasilkan keuntungan yang layak bila telah dioperasionalkan (Umar, 2000:24). Studi kelayakan dibutuhkan untuk menelaah atau menganalisis suatu kegiatan investasi apakah memberikan manfaat atau hasil bila dilaksanakan (Nurmalina dalam Abdi Tri Sulistyo, 2013).

Aspek-aspek dalam suatu proyek memiliki hubungan antara satu dengan yang lainnya dan suatu keputusan terhadap suatu aspek akan mempengaruhi keputusan pada aspek- aspek yang lain.

1) Analisis Aspek Pasar

2) Analisis Aspek Teknis/produksi

a) Penentuan letak proyek

b) Luas produksi

c) Pemilihan teknologi

3) Analisis Aspek Manajemen

4) Aspek Lingkungan

5) Aspek Hukum

$\underline{\text { Tinjauan Empiris }}$

Mengutip Skripsi dari Mega Indah Mujiningsih, yang berjudul 
Analisis kelayakan usaha dan strategi pengembangan industri kecil tempe di Kecamatan Matesih Kabupaten Karang Anyar, Pendekatan yang digunakan dalam penelitian ini adalah menggunakan analisis BCR ratio yaitu melihat apakah usaha yang dijalankan menguntukan atu tidak. Dan pendekatan IRR dan NPV yaitu Suatu bisnis dikatakan layak jika nilai NPV lebih besar dari nol $(\mathrm{NPV}>0)$, yang memiliki arti bahwa bisnis menguntungkan atau memberikan manfaat. Berdasarkan hasil penelitian usaha industri kecil tempe di Kecamatan Matesih Kabupaten Karanganyar layak dijalankan karena memiliki nilai NPV positif, nilai BCR > 1 dan nilai IRR adalah sebesar $38,72 \%>$ bunga pinjaman (14\%). Mengutip skripsi dari Syahreza Yumanda (2009), yang berjudul Strategi pemasaran keripik singkong industri rumah tangga cap kelinci di Tanjung Marowa Kabupaten Deli Serdang. Berdasarkan hasil penelitian, Jumlah skor pembobotan pada peluang yaitu 3,14 masih di bawah nilai dari kekuatan yaitu 3,28. Jumlah skor pembobotan pada Kekuatan lebih besar yaitu 3,28 dibanding skor pembobotan pada ancaman yaitu 2,40 . Jumlah skor pembobotan Kelemahan lebih rendah yaitu 1,75 dibanding dengan skor pembobotan peluang yaitu 3,14. Jumlah skor pembobotan Kelemahan lebih rendah yaitu 1,75 dibanding dengan skor ancaman 2,40.

\section{$\underline{\text { Hipotesis }}$}

Diduga usaha amplang ikan di Kota Tarakan layak untuk dikembangkan berdasarkan aspek finansial.

\section{$\underline{\text { Kerangka Penelitian }}$}

Kerangka penelitian menjelaskan bahwa dengan adanya strategi pengembangan makapengusaha dapat melihat kondisi perusahaan dengan seksama, dengan adanya prospek yang baik maka akan tersedia lapangan pekerjaan untuk mengurangi tingkat pengangguran demi mewujudkan kesejahteraan masyarakat.

\section{METODOLOGI PENELITIAN}

\section{Desain Penelitian}

Desain penelitian ini menggunakan metode deskriptif dengan pendekatan kualitatif dan kuantitatif. Pendekatan kualitatif yaitu penelitian yang cenderung menggunakan analisis atau kata-kata dengan mendeskripsikan objek yang diteliti, sedangkan pendekatan kuantitatif yaitu pendekatan yang menggunakan angka yang diperoleh dari sampel pupulasi, penelitian dianalisis sesuai dengan metode statistik yang digunakan kemudian di interpretasikan. Objek, Lokasi Penelitian dan Waktu Penelitian Objek dari penelitian ini adalah strategi pengembangan dan uji kelayakan usaha amplang ikan di Kota Tarakan. Lokasi penelitian ini di laksanakan di Kota Tarakan, Kalimantan Utara. Sedangkan waktu penelitian ini dilakukan pada bulan Mei sampai bulan Juni 2018.

Populasi dan Sampel Populasi adalah wilayah generalisasi yang terdiri atas subjek atau dengan 
kualitas dan karakteristik tertentu yang ditetapkan oleh peneliti untuk dipelajari dan kemudian ditarik kesimpulannya (Sabfadji \& Sofiah, 2010:185). Populasi dalam penelitian ini adalah seluruh pengusaha amplang ikan di Kota Tarakan. Sampel adalah bagian dari jumlah dan karakteristik yang dimiliki oleh populasi (Sabfadji \& Sofiah, 2010:186). Teknik pengumpulan sampel penelitian ini yaitu nonprobability sampling yang dilakukan dengan menggunakan teknik sensus atau teknik sampel jenuh. Sampel jenuh merupakan teknik penentuan sampel bila semua anggota populasi dipilih sebagai sampel (Martono, 2012: 79).

\section{$\underline{\text { Data Penelitian }}$}

Data primer merupakan data yang diperoleh langsung di lapangan oleh peneliti sebagai objek penulisan (Umar, 2003:56). Data primer penelitian ini diperoleh langsung dari pengusaha amplang ikan di Kota Tarakan melalui penyebaran kuesioner.

Data sekunder merupakan data yang tidak langsung memberikan data kepada peneliti, misalnya harus melalui orang lain atau mencari melalui dokumen (Sugiyono, 2005:62). Data sekunder penelitian ini diperoleh dari instansi atau dinas yang terkait yaitu DISDAGKOP (DinasPerdagangan dan Koperasi) Kota Tarakan.

\section{$\underline{\text { Definisi Operasional }}$}
1. Strategi
pengembangan
Keberhasilan pengembangan dapat dilihat dari kekuatan dan

peluang yang dimiliki usaha ampalang ikan di Kota Tarakan.

2. Kelayakan Layak tidaknya UKM amplang ikan tergantung pada aspek finansial yang diperoleh dari perbandingan antara penerimaan dan biaya.

\section{Metode Analisis Data}

Analisis SWOT (strength, weakness, opportunity, threat) Analisis SWOT adalah identifikasi berbagai faktor secara sistematis untuk merumuskan strategi. Analisis ini didasarkan pada logika yang dapat memaksimalkan kekuatan (strength) dan peluang (opportunity), namun secara bersamaan dapat meminimalkan kelemahan (weakness) dan ancaman (threat). Hal ini disebut dengan analisis situasi. Model yang paling populer untuk analisis situasi adalah analisis SWOT (Freddy Rangkuti, 2006:7).

Terdapat empat kuadran dalam menganalisis situasi dalam suatu usaha, yaitu:

1. Kuadran I : Merupakan situasi yang sangat menguntungkan, perusahaan tersebut memiliki peluang dan kekuatan

2. sehingga dapat memanfaatkan peluang yang ada. Strategi yang diterapkan dalam kondisi ini adalah mendukung kebijakan pertumbuhan yang agresif (growth oriented strategy).

3. Kuadran II : Meskipun menghadapi berbagai ancaman, perusahaan ini masih memiliki kekuatan dari segi internal. Strategi yang harus diterapkan adalah menggunakan kekuatan untuk memanfaatkan peluang jangka panjang dengan cara 
strategi diversifikasi (produk/pasar). Kuadran III : Perusahaan menghadapi peluang pasar yang sangat besar, tetapi di lain pihak menghadapi beberapa kendala atau kelemahan internal. Fokus strategi perusahaan ini adalah meminimalkan masalahmasalah internal perusahaan sehingga dapaat merebut peluang pasar yang lebih baik.

4. Kuadran IV : Merupakan situasi yang sangat tidak menguntungkan, perusahaan tersebut menghadapi berbagai ancaman dan kelemahan internal.

\section{$\underline{\text { Analisis Kelayakan Finansial }}$}

1. BCR (Benefit Cost Ratio) Analisis Benefit Cost of Ratio merupakan perbandingan antara pendapatan bersih atau hasil penjualan dengantotal biaya pemeliharan, Suatu kegiatan investasi atau bisnis bisa dikatakan layak jika Net B/C lebih besar dari satu maka layak dilaksanakan dan dapat dikatakan tidak layak jika Net B/C lebih kecil dari satu (Nurmalina, 2009).

Dimana : Benefit = manfaat/Pendapatan bersih Cost $=$ Biaya pemeliharaan Kesimpulan: $\quad$ BCR $>1$, artinyausaha amplang ikan di Kota Tarakan layak untuk dilaksanakan dan menguntungkan $\mathrm{BCR}=1$, artinya usaha amplang ikan di Kota Tarakan tidak untung dan tidak rugi $\mathrm{BCR}<1$, artinya usaha amplang ikan di Kota tarakan merugikan atau tidak layak untuk dilaksanakan
2. NPV (Net Present Value) Menurut (Kasmir dan Jakfar, 2007:100), Net Present Value atau nilai bersih sekarang merupakan perbandingan antara PV kas bersih (PV of proceed) dengan PV investasi (capital Outlays) selama umur investasi.

Dimana: NPV : Net Present Value NCF1: Net Cash Flow tahun ke-1 NCF2: Net Cash Flow tahun ke-2 I : Investasi Kesimpulan: NPV > 0 ,artinyainvestasi yang dilakukan memberikan manfaat bagi perusahaan, proyek bisa dijalankan NPV $<0$,artinyainvestasi yang dilakukan akan mengakibatkan kerugian bagi perusahaan, proyek ditolak NPV $=0$, artinyainvestasi yang dilakukan tidak mengakibatkan perusahaan untung ataupun rugi.

3. FRR (Financial Rate of Return) Merupakan perbandingan antara penghasilan bersih dengan investasi yang ditanamkan (Riyanto, 1995).

Dimana: NI = Net Income (Pendapatan Bersih) I= Investasi Nilai FRR berguna untuk menentukan apakah modal yang dimiliki di investasikan pada suatu usaha atau disimpan di bank. Bila nilai FRR lebih besar dari suku bunga bank berarti modal yang dimiliki oleh pengusaha lebih baik di investasikan dan sebaliknya.

4. PBP (Pay Back Period) Pay Back Period adalah lamanya waktu yang diperlukan agar modal yang ditanamkan pada investasi diperoleh kembali seluruhnya dalam jangka waktu tertentu. 
Semakin kecil nilai PP semakin cepat masa pengembalian modal. Kesimpulan: Periode pengembalian lebih cepat = layak

Periode pengembalian lebih lama = tidak layak

5. Break Even Point (BEP) digunakan untuk menganalisis proyek sejauh mana banyaknya jumlah unit yang diproduksi atau sebanyak apa uang yang harus diterima untuk mendapatkan titik impas atau kembali modal. Break Even Point adalah titik impas di mana posisi jumlah pendapatan dan biaya sama atau seimbang sehingga tidak terdapat keuntungan ataupun kerugian dalam suatu perusahaan atau bisnis

\section{$\underline{\text { Pengujian Hipotesis }}$}

Hipotesis dari penelitian ini yaitu industri amplang di Kota Tarakan layak berdasarkan aspek finansial dengan pengujian Benefit Cost of ratio (BCR $>1)$, Net Present Value $(N P V>0)$, Financial Rate of Return (FRR > suku bunga bank), Pay Back Period (PBP lebih cepat dikembalikan) dan Break Even Point pada (BEP dasar unit dan dasar penjualan yaitu sama dengan nol).

\section{HASIL DAN PEMBAHASAN}

Gambaran Umum UKM di Kota $\underline{\text { Tarakan }}$

Pengembangan

UKM

diharapkan mendorong tumbuhnya sentra usaha mikro kecil menengah di Kalimantan Utara yang berbasis produk unggulan lokal, seperti agroindustri dan kelautan, sehingga tercipta keberlanjutan pembangunan di wilayah ini. UKM amplang ikan merupakan salah satu usaha yang tergolong industri rumahan yang berada di Kota Tarakan. Industri ini cukup potensial karena berkontribusi menyerap tenaga kerja dan mengurangi jumlah pengangguran. Jumlah pengusaha amplang ikan pada tahun 2018 di Kota ini sebanyak 14 pengusaha. Saat ini industri amplang semakin banyak ditekuni oleh wanita lainnya karena penghasilan amplang sangat menjanjikan. Dimana saat ini permintaan amplang semakin meningkat, pemasaran tidak hanya di kota Tarakan tetapi diluar kota seperti Balikpapan, Sebatik, Tanjung selor, dan Makassar.

Karakteristik Responden Jenis Kelamin Pengusaha Amplang Ikan Berdasarkan hasil penelitian, Jenis Kelamin Jumlah Persentase (\%) 1 Perempuan 12 85,71 2 Lakilaki 2 14,29 Total 14100 Sumber: Data Primer diolah, 2018 Jenis kelamin pengusaha amplang ikan di kota Tarakan adalah perempuan sebanyak 12 orang $(85,71 \%)$ dan laki-laki sebanyak 2 orang $(14,29 \%)$. Berdasarkan data di atas dapat diketahui bahwa sebagian besar jenis kelamin pengusaha amplang ikan adalah perempuan.

Usia Pengusaha Amplang Ikan Usia pengusaha dapat mempengaruhi kinerja dalam kontribusinya mengembangkan usaha yang dijalankan. Apabila pengusaha memiliki usia yang produktif, dengan stamina dan pemikiran yang logis ditambah pengalaman kerja yang maksimal maka akan memberi dampak positif 
terhadap usaha yang dijalankan. Berdasarkan hasil penelitian di lapangan, dapat diketahui bahwa sebagian besar pengusaha amplang ikan berusia antara 30-40 tahun yaitu sebanyak 7 orang $(50 \%)$.

Tingkat Pendidikan

Pengusaha Amplang Ikan Berdasarkan hasil penelitian, latar belakang pendidikan pengusaha amplang pada usahaamplang Tingkat pendidikan pengusaha amplang ikan di Kota Tarakan adalah SD sebanyak 4 orang $(28,57 \%)$, SMP sebanyak 1 orang $(7,14 \%), \quad$ SMK/SLTA sebanyak 6 orang $(42,86 \%)$, D3 sebanyak 2 orang $(14,29 \%)$ dan S1 sebanyak 1 orang $(7,14 \%)$. Berdasarkan data di atas (Tabel 4.3) dapat diketahui bahwa sebagian besar tingkat pendidikan pengusaha amplanga dalah SMA/SMK.

Pekerjaan Pokok Pengusaha Amplang menunjukkan bahwa responden dalam penelitian ini berdasarkan pekerjaan pokok pengusaha amplang di Kota Tarakan wirausaha berjumlah 9 orang $(64,29 \%)$, ibu rumah tangga (IRT) berjumlah 3 orang $(21,43 \%)$, guru berjumlah 1 orang $(7,14 \%)$ dan desain grafis berjumlah 1 orang $(7,14 \%)$. Dengan demikian dapat disimpulkanbahwa sebagian besar pekerjaan pokok pengusaha amplang adalah sebagai wirausaha.

Lama Usaha Amplang Ikan Berdasarkan hasil penelitian adalah dengan lama usaha $<5$ tahun sebanyak 10 usaha $(71,43 \%)$, lama usaha 5-10 tahun sebanyak 3 usaha $(21,43 \%)$ dan lama usaha>10 tahun sebanyak 1 usaha $(7,14 \%)$. Berdasarkan data di atas (Tabel 4.5) dapat diketahui bahwa sebagian besar lama usaha pengusaha amplang yaitu $<5$ tahun.

Jumlah Tenaga Kerja Pada Usaha Amplang Ikan Berdasarkan hasil penelitian adalah Jumlah tenaga kerja amplang di Kota Tarakanberjumlah 1-5 orang sebanyak 6 (42,86\%), >5orang sebanyak $1 \quad(7,14 \%)$ dan tidak memiliki tenaga kerja berjumlah 7 $(50 \%)$.

Hasil Analisis Kelayakan Finansial Usaha Amplang Ikan

1. Benefit Cost of Ratio (BCR) $\mathrm{BCR}=1,025316456$ atau 1,03

BCR > 1 (Layak) Berdasarkan hasil perhitungan diketahui bahwa nilai BCR yaitu sebesar 1,03. Maka dapat disimpulkan bahwa nilai $\mathrm{BCR}>1$ maka usaha layak untuk dijalankan.

2. Net Present Value Tahun Net Cash Flow/arus kas bersih Faktor $\mathrm{NPV}=172.927 .700,60>0$ (layak) Berdasarkan hasil perhitungan diketahui bahwa nilai NPV yaitu sebesar 172.927.700,60. Maka dapat disimpulkan bahwa nilai NPV > 0 maka usaha layak untuk dijalankan.

3. Financial Rate of Return FRR $\mathrm{FRR}=98,51 \%$

Berdasarkan hasil perhitungan diketahui bahwa nilai FRR yaitu sebesar 98,51\%. Diketahui nilai suku bunga bank yang berlaku 7\% maka dapat disimpulkan bahwa nilai FRR lebih besar dari pada nilai suku bunga bank yang berlaku sehingga modal usaha yang dimiliki lebih baik di investasikan atau layak untuk di investasikan 
4. Pay Back Period (PBP) $\mathrm{PBP}=$ $1,015089163 \quad \mathrm{PBP}=1,02$

Dari hasil perhitungan diketahui bahwa nilai payback period sebesar 1,02 maka dapat diketahui bahwa lamanya waktu pengembalian modal yang ditanamkan pada investasi yaitu sekitar 1 tahun.

5. Break Even Point Unit

BEP Unit $=1.500 \times 12.000$ BEP

Penjualan $=18.000 .000$

Hasil Strategi Pengembangan Usaha Amplang Ikan

Matriks IFE (Internal Faktor Evaluation)

Faktor Internal Bobot (B)

Rating (R) Skor (B X R)

Kekuatan

1. Bahan baku mudah di dapat

2. Usaha pokok

3. Modal sendiri

4. Peralatan produksi mudah di dapat

5. Ketersediaan tenaga kerja

6. Teknologi produksi sederhana

Sub Total $0.71 \quad 1,98$

Kelemahan

1. Modal terbatas

2. Kemasan kurang menarik

3. Kurangnya promosi

Sub Total $0.29 \quad 0.71$ Total Skor 1.002 .69

\footnotetext{
UKM amplang ikan memiliki enam kekuatan yang bisa dimanfaatkan.

Faktor kekuatan terbesar yang dimiliki pengusaha amplang yaitu usaha pokok dengan skor 0,35 . Hal ini dikarenakan pengusaha amplang fokus dalam mengelola
}

usaha amplang karena merupakan pekerjaan utama untuk menghasilkan keuntungan. Selanjutnya bahan baku mudah diperoleh dan ketersediaan tenaga kerja dengan skor yang sama yaitu 0,34 .

Dengan adanya bahan baku yang mudah diperoleh maka akan memudahkan pengusaha dalam memproduksi amplang melebihi permintaan konsumen. Dengan banyaknya produksi akan memperluas pangsa pasar dengan memasuki seluruh pasar yang ada di Kota Tarakan. Begitu pula ketersediaan tenaga kerja, hal ini yang dimaksud adalah bantuan untuk mempercepat proses produksi, contohnya adanya keluarga dapat dimanfaatkan untuk menjadi tenaga kerja dan membuka lapangan kerja untuk masyarakat sekitar guna mengurangi pengangguran.

Selanjutnya peralatan produksi mudah di dapatkan dan teknologi produksi sederhana dengan skor 0,33 . Peralatan produksi sangat dibutuhkan oleh pengusaha amplang, mudahnya peralatan di dapatkan akan membantu pengusaha amplang dalam memenuhi peralatan dan perlengkapan yang dibutuhkan. Begitu juga dengan teknologi produksi yang sederhana artinya teknologi yang digunakan dalam proses produksi tidak sulit untuk dioperasikan. Selanjutnya modal sendiri dengan skor 0,29. Dengan adanya modal sendiri maka tidak ada beban yang di khawatirkan untuk mengganti atau membayar angsuran yang dipinjam contohnya pinjaman di bank. Pada tabel diatas terlihat bahwa UKM amplang ikan mempunyai tiga kelemahan yang harus diatasi. Faktor kelemahan 
terbesar yang dihadapi pengusaha amplang adalah kemasan kurang menarik dengan skor 0,30 . Hal ini akan mengurangi minat masyarakan untuk membeli karena melihat kemasan yang kurang menarik. Hal ini dikarenakan jika konsumen membeli produk, mereka tidak langsung menilai kualitas rasa malainkan kemasan dari produk tersebut. Jika kemasannya menarik maka konsumen akan membelinya meski belum tahu kualitas rasanya. Selanjutnya kurangnya promosi dengan skor 0,22. Promosi usaha amplang ikan masih terbatas seperti kurangnya promosi melalui sosial media. Selanjutnya modal terbatas dengan skor 0,19. Keterbatasan modal akan menghambat kegiatan usaha sehingga perlu adanya modal yang memadai untuk kelangsungan usaha agar berjalan dengan baik.

\section{Matriks EFE (Eksternal Faktor Evaluation) \\ Matriks EFE Usaha Amplang Ikan Faktor \\ Eksternal Bobot (B) \\ Rating (R) \\ (B X R)}

\section{Peluang}

1. Permintaan pasar cukup tinggi

2. Adanya sosialisasi yang diadakan pemerintah

3. Ketersediaan pedagang perantara

4. Lokasi pemasaran dekat

Sub Total $\quad 0.67 \quad 2.01$

Ancaman

1. Banyaknya pesaing baru

2. Membutuhkan biaya besar untuk perijinan

Sub Total $0.33 \quad 0.89$ Sub Skor 1.002 .90
Faktor peluang dapat dimanfaatkan oleh pengusaha dengan skor tertinggi adalah lokasi pemasaran dekat dengan skor 0,63. Hal ini akan memudahkan konsumen dalam menjangkau produk yang di hasilkan dan menguntungkan pengusaha amplang karena produk yang dihasilkan akan mudah terjual dengan adanya lokasi pemasaran yang dekat dengan konsumen. Selanjutnya adanya sosialisasi yang diadakan pemerintah dengan skor 0,49. Hal ini di karenakan kebijakan yang dilakukan seperti sosialisasi tentang UMKM (Usaha mikro kecil menengah) untuk menambah wawasan pengusaha dalam mengembangkan usahanya. Selanjutnya permintaan pasar cukup tinggi dengan skor 0,46. Hal ini dikarenakan permintaan amplang ikan tidak hanya terbatas di Kota Tarakan, tapi di luar Kota Tarakan permintaan pun semakin meningkat. Selanjutnya ketersediaan pedagang perantara dengan skor 0,44. Hal ini akan memberi keuntungan bagi pengusaha amplang dengan adanya supermarket, pasar dan toko kecil dalam melakukan proses penjualan amplang tanpa harus menguras tenaga. Selanjutnya ancaman terbesar yang dihadapi pengusaha UKM amplang ikan yaitu membutuhkan biaya yang cukup besar dengan skor 0,46. Biaya ini dimaksudkan untuk membuat surat izin halal dan menilai kelayakan usaha tersebut dengan mendatangkan tim pemeriksaan dari luar Kota Tarakan. Selanjutnya adanya pesaing baru dengan skor 0,43. Dengan adanya pesaing baru, akan mengurangi jumlah penjualan amplang karena masyarakat pada 
umumnya lebih memilih produk yang baru untuk mencoba kualitas rasanya.

\section{Diagram dan Matriks SWOT}

Berdasarkan nilai skor dari tabel EFE dan IFE bahwa perioritas strategi usaha amplang ikan ini adalah strategi SO dilihat dari gambar diagram analisis SWOT diatas dimana strategi ini berdasarkan jalan pikiran suatu usaha, yaitu dengan memanfaatkan seluruh kekuatan untuk merebut dan memanfaatkan peluang sebesarbesarnya. Setelah posisi usaha diketahui kemudian dilakukan formulasi alternatif strategi dengan menggunakan matriks SWOT.

Kekuatan (S)

1. Bahan baku mudah di dapatkan

2. Usaha pokok

3. Modal sendiri

4. Peralatan produksi mudah di dapat

5. Ketersediaan tenaga kerja

6. Teknologi produksi mudah

Kelemahan (W)

1. Modal terbatas

2. Kemasan kurang menarik

3. Kurangnya promosi

Peluang $(\mathrm{O})$

1. Permintaan pasar cukup tinggi

2. Adanya sosialisasi pemerintah

3. Ketersediaan pedagang perantara

4. Lokasi pemasaran dekat

Ancaman (T)

1. Banyaknya pesaing baru

2. Membutuhkan biaya besar untuk perijinan

\section{Strategi SO}

1. Mengoptimalkan pengelolaan usaha dan menambah jumlah produksi dengan memanfaatkan tenaga kerja yang tersedia. (S1,S2,S4,S5,S6,O1,O4)

2. Memanfaatkan teknologi serta bekerjasama dengan pemerintah daerah untuk memperluas pasar. (S3,S5,S6,O2,O3,O4)

\section{Strategi WO}

1. Melakukan kerja sama dengan beberapa pihak dalam memperkuat modal dan memperbanyak promosi produk. (W1,W3,O1,O2,O3)

2. Memanfaatkan bantuan dari pemerintah daerah dalam meningkatkan kualitas produk. (W2,O2)

\section{Strategi ST}

1. Meningkatkan kualitas produk dan mempertahankan ciri khas cita rasa produk yang dimiliki. (S2,S4,S5,S6,T1,)

2. Melakukan kerja sama dengan pemerintah dan pihak-pihak lain dalam pengadaan perizinan. (S2,T2)

\section{Strategi WT}

1. pengadaan inovasi dan diversifikasi produk agar produk memiliki daya tarik yang kuat. (W1,W2,W3,T1)

2. Pengadaan kerja sama dengan pengusaha lain dari luar wilayah untuk peningkatan kualitas dan pemasaran produk. (W2,W3,T1)

Pembahasan analisis Kelayakan Finansial Berdasarkan hasil perhitungan analisis kelayakan finansial usaha amplang ikan di Kota 
Tarakan didapatkan hasil Perhitungan BCR (Benefit Cost of Ratio) menghasilkan nilai 1,03. Nilai BCR tersebut berarti bahwa nilai manfaat yang diperoleh dalam usaha ini adalah sebesar 1,37 kali lipat dari nilai biaya yang dikeluarkan pada tingkat bunga sebesar 7\%. Karena nilai BCR lebih besar daripada satu maka usaha amplang ikan di kota Tarakan layak di jalankan.

Berdasarkan hasil perhitungan analisis kelayakan usaha didapatkan hasil NPV (Net Present Value) dari UKM amplang ikan sebesar Rp. 172.927.700,60. Oleh karena nilai NPV lebih besar daripada nol, maka usaha amplang di Kota Tarakan layak dijalankan.

Nilai FRR (Financial Rate of Return) adalah sebesar 98,51\%. Karena nilai ini lebih besar daripada tingkat bunga bank sebesar 7\% maka dapat disimpulkan bahwa usaha ampalng layak untuk dijalankan. Nilai PBP (Pay Back period) pada usaha amplang ikan di Kota Tarakan adalah sebesar 1.02 dengan periode pertahun maka lama pengembalian modal yang ditanamkan pada usaha ini yaitu sekitar 1 tahun. Maka hasil dari penelitian adalah usaha amplang ikan di Kota Tarakan layak untuk dikembangkan atau dilanjutkan dengan pengembalian modal usaha sekitar 1 tahun. Berdasarkan hasil perhitungan analisis kelayakan usaha didapatkan hasil Break even Point (BEP) atas dasar unit yaitu 1.500 bungkus dan BEP atas dasar penjualan sebesar Rp18.000.000. Dapat disimpulkan bahwa titik impas yaitu apabila dilakukan penjualan sebanyak 1.500 bungkus atau sebesar penjualan Rp18.000.000. $\underline{\text { Pembahasan Strategi Pengembangan }}$

Dari hasil strategi pengembangkan didapatkan hasil bahwa posisi strategi usaha ini berada pada posisi kuadran I dengan skor tertinggi yaitu 4,00 dimana kuadran ini mendukung strategi yang agresif. Kuadran I ini menggunakan strategi SO dimana Strategi ini berdasarkan jalan pikiran suatu usaha, yaitu dengan memanfaatkan seluruh kekuatan untuk merebut dan memanfaatkan peluang sebesarbesarnya.

Alternatif strategi terbaik yang dapat diciptakan dari Strategi SO adalah sebagai berikut:

1. Mengoptimalkan pengelolaan usaha dan menambah jumlah produksi dengan memanfaatkan tenaga kerja yang tersedia. (S1,S2,S4,S5,S6,O1,O4).

Mengoptimalkan pengelolaan serta menambah jumlah produksi bertujuan untuk meningkatkan hasil produksi dan memperluas pangsa pasar dengan tujuan meningkatkatkan pendapatan pengusaha amplang ikan

2. Memanfaatkan teknologi produksi serta bekerjasama dengan pemerintah daerah untuk memperluas pasar. (S3,S5,S6,O2,O3,O4).

Memanfaatkan teknologi produksi bertujuan untuk mempercepat proses produksi berlangsung serta bekerjasama dengan pemerintah daerah untuk memperluas pasar dengan cara mengikuti sosialisasi atau bimbingan yang di berikan pemerintah daerah. 


\section{KESIMPULAN DAN SARAN}

$\underline{\text { Kesimpulan }}$

1. Berdasarkan hasil penelitian, analisis kelayakan usaha amplang ikan di Kota Tarakan dapat disimpulan bahwa BCR (Benefit Cost of Ratio) sebesar 1.03, NPV (Net Present Value) sebesar 172.927.700,60, FRR (Financial Rate of Return) sebesar 98,51\%, PBP (Pay Back Period) sebesar 1,02 dan BEP (Break Even Point) dasar harga unit sebanyk 15,000 bungkus dan dasar harga penjualan sebesar Rp18.000.000. Dapat disimpulkan bahwa UKM amplang di Kota Tarakan berdasarkan kriteria uji kelayakan BCR, NPV, FRR, PBP dan BEP layak untuk dioperasionalkan

2. Dari anlisis situasi didapatkan bahwa strategi yang digunakan dalam pengembangan usaha tersebut yaitu strategi SO (Strength-Opportunity) dengan penetapan strategi agresif yang artinya menggunakan semua kekuatan yang dimiliki untuk merebut peluang yang ada secara maksimal.

$\underline{\text { Saran }}$

Berdasarkan pembahasan mengenai strategi pengembanagan dan uji kelayakan UKM amplang di Kota Tarakan di atas, saran yang dapat diberikan adalah:

1. Untuk pengusaha amplang di Kota Tarakan diharapkan mampu menganalisis situasi atau kondisis perusahaannnya baik secara internal maupun eksternal untuk memaksimalkan laba.

2. Untuk pemerintah diharapka agar terus memberikan bantuan baik finansial maupun non finansial, seperti memberikan dukungan, sosialisasi serta bimbingan guna menambah minat dan memberikan motivasi.

3. Untuk penelitian selanjutnya diharapkan pengusaha amplang dapat meberikan informasi secara detail mengenaai amplang ikan khususnya untuk menilai kelayakan finansial yaitu mengenai biaya-biaya yang dikeluarkan atau biaya operasional baik biaya variable maupun biaya tetap.

\section{DAFTAR PUSTAKA}

Abdul Halim Muhammad. 2012, Teori Ekonomika. Tangerang: Jelajah Nusa

Alma, Buchari. 1992. Manajemen Pemasaran dan Pemasaran Jasa. Bandung: Alfabeta.

Arikinto Suharsimi, 2006. Prosedur Penelitian Suatu Pendekatan Praktik, Jakarta: Rineka Cipta

Arsyad, Lincolin. 2010. Ekonomi Pembangunan. Edisi Kelima. Yogyakarta: UPP STIM YKPN

Gaspersz, Viencent. 2006. Manajemen Produktivitas Total Strategi Peningkatan Produktivitas Bisnis Global. Jakarta: Gramedia Pustaka Utama

Husein Umar, 2003. Metodologi Penelitian Untuk Skripsi dan tasis Bisnis, Jakarta: PT. Gramedia Pustaka 
Husein Umar. 2005.Studi Kelayakan Bisnis, Edisi 3 , Jakarta: Gramedia Pustaka Utama.

Kasmir dan Jakfar, 2007. Studi Kelayakan Bisnis, Edisi 2, Jakarta: Kencana Prenada

Kolter,Philip. 1995. Manajemen Pemasaran, Analisis, Perencanaan, Implementasi dan Pengendalian (Ahli Bahasa

Ancella Anitawati Hermawan SE, MBA), Jakarta: Salemba Empat

Kotler Philip, 2008. Prinsip-Prinsip Pemasaran. Edisi 12 Jilid 1, Jakarta: Erlangga

Machfoedz, Mahmud. 2010. Komunikasi Pemasaran Modern. Yogyakarta: Cakra Ilmu.Gramedia Pustaka Utama.

Martono, Nanang. 2012. Metode Penelitian Kuantitatif: Analisis Isi Dan Data Skunder. Jakarta: PT. Raja Grafindo Persada.

Mujiningsih Mega Indah. 2013. Analisis Kelayakan Usaha dan Strategi Pengembangan Industri Kecil Tempe di Kecamatan Matesih Kabupaten Karang Anyar.Skripsi.Semarang:Uni vers itas Negeri Semarang

Rahman Arief, dkk. 2010. Strategi pengembangan idsutri kecil menengah sektor pengolahan. Universitas Widyatama

Rangkuti, Freddy .2009. Strategi Promosi yang Kreatif dan Analisis Kasus Integrated Marketing

Communication.Jakarta : PT. Gramedia Pustaka Utama
Rangkuti, Freddy.2012. Studi Kelayakan Bisnis \& Investasi. Jakarta: PT. Gramedia Pustaka Utama

Rangkuti, Freddy.2015. Teknik Membedah Kasus Bisnis. Jakarta: PT. Gramedia Pustaka Utama.

Santi Yenny Mailya. 2009. Analisis Usaha Agroindustri Keripik Belut Sawah di Kabupaten Klaten.Skripsi. Universitas Sebelas Maret.

Situmorang, J. 2008.Strategi UMKM

Dalam Menghadapi Iklim Usaha yang Tidak Kondusif, Indikop, Volume 16, Hal 88101.

Suad Hasnan dan Suwarsono. 2001.

Studi Kelayakan Proyek.

UPP AMP

YKPN.Yogyakarta

Sopiah dan Sangadji, Mamang, Etta.2010.”Metodologi

Penelitian Pendekatan Praktis

Dalam

Penelitian.Yogyakarta:C.V

Andi Offset.

Sri Winarni. 2006. Strategi

Pengembangan Usaha Kecil

Melalui Peningkatan

Aksesibilitas Kredit

Perbankan. Infokop Nomor 29 Tahun XXII, 2006.

Sudrajat,S.E. 2005.Kiat

Mengentaskan Pengangguran Melalui Wirausaha.

Jakarta:Bumi Aksara

Sugiyono, R. G. 2005. Memahami Penelitian Kualitatif . Bandung: Alfabeta.

Sugiyono, 2009. Statistika utuk Penelitian, Cetakan Keduabelas , Bandung: Alfabeta 
Sugiyono, 2013. Metodologi Penelitian Kuantitatif, dan Kualitatif. Bandung: Alfabeta Sumarsono, Sonny. 2004. Metode Riset Sumber Daya Manusia, Yogyakarta: Graha Ilmu

Supomo, Bambang. 2002. Metode Penelitian Bisnis untuk Akuntansi dan Manajemen. Edisi Pertama. Yogyakarta: BPFE

Tambunan, Tulus. 2005. Promoting Small and Medium Enterprises with a Clustering Approach: A policy Experience From Indonesia. Journal of Small BusinessManagement, Vol. 43, No 2, pp.138-154

Umar, Husein. 2003. Studi Kelayakan Bisnis. Edisi ke 2.
Jakarta: PT. Gramedia Pustaka Umum

Umi Narimawati. 2007. Riset Manajemen Sumber Daya Manusia. Jakarta: Agung Media

Wahyuniarso Tri D S. 2013.Strategi Pengembangan Industri Kecil Keripik di Dusun Karangbolo Desa Lerep Kabupaten Semarang.Skripsi.

Universitas Negeri Semarang. Yumanda Syahreza. 2009. Strategi pemasaran keripik singkong industri rumah tangga cap kelinci di Tanjung Marowa kabupaten Deli Serdang.Skripsi. Universitas Sumatera Utara 